\title{
FURTHER BENEFITS OF XYLANASE ENZYME SUPPLEMENTATION TO LOW ENERGY CORN-SOYBEAN MEAL BROILER DIETS
}

\author{
Nessrin A. Selim, Amany H. Waly, Hemat A. Abdel Magied, Heba H. Habib, A.A. Fadl \\ and S.M. Shalash \\ Department of Poultry Nutrition, Animal Production Research Institute, ARC, Dokki, Giza-12618, \\ Egypt
}

Corresponding author: hemat1018@yahoo.com

(Received 1/10/2015, Accepted 29/11/2015)

\section{SUMMARY}

$\mathrm{T}$ This experiment was conducted to study the ability of supplemental xylanase enzyme (Xyl) to improve growth performance, carcass traits, meat quality and feeding cost of broilers fed on low metabolizable energy (ME) corn-soybean meal diets. Two hundred and forty, one day old unsexed Arbor Acres broiler chicks were randomly distributed into six treatments (2x3 factorial design) each had four replicates. Chicks were fed on corn-soybean diet supplemented with two levels of Xyl (0 and $16000 \mathrm{U} / \mathrm{kg}$ of diet), and three ME levels which were standard strain recommendation (STD), $100 \mathrm{kcal}$ lower than STD (E100) and $150 \mathrm{kcal}$ lower than STD (E150) of each feeding phase for STD, E100, and E150 levels, respectively. The dietary ME values were 3000, 2900 and $2850 \mathrm{kcal} / \mathrm{kg}$ diet at starter phase; 3100,3000 and $2950 \mathrm{kcal} / \mathrm{kg}$ at grower phase; and 3200, 3100 and $3050 \mathrm{kcal} / \mathrm{kg}$ at the finisher phase. All diets were formulated to save the strain requirements from the rest of nutrients. All chicks were housed in open system broiler house and received the same managerial conditions and veterinary program during experimental period (1-40 d of age). Parameters of growth performance, carcass characteristics, physical and chemical evaluation of broiler meat were carried out and feeding cost was calculated. The recorded results showed that xylanase supplementation to broiler diets resulted in significant improvement of body weight, body weight gain, feed conversion ratio, dressing \%, and breast meat yield \%, while feed intake and ultimate $\mathrm{pH}(\mathrm{pHu})$ of both breast and thigh cuts were decreased. Regarding to ME of diets, reducing ME values from STD level to E150 level caused significant reduction in final body weight, abdominal fat \%, $\mathrm{pHu}$ of breast meat samples and concentrations of malondialdehyde (MDA) and low density lipoprotein (LDL). Furthermore this reduction of ME levels caused significant increase of feed intake, $\%$ of drum stick and concentration of total protein of broiler meat at $40 \mathrm{~d}$ of age. Among experimental treatments chicks of both STD+Xyl and E100+Xyl treatments showed better growth performance, carcass traits, and meat quality compared with other treatments. In addition applying these treatments resulted in saving $9.25 \%$ and $3.51 \%$ from feeding cost $/ \mathrm{kg}$ of body weight relative to feeding cost of STD group. According to these results it could be concluded that adding xylanase enzyme to either STD or E100 corn-soybean meal broiler diets could enhance the quality of produced broiler accompanied with saving in feeding cost.

Keywords: broiler, xylanase, metabolizable energy, performance, meat quality.

\section{INTRODUCTION}

Both reducing feeding cost at commercial poultry farms and producing better quality of broiler meat are the most important targets of producers in the field of poultry industry and this led to an increasing interest in using exogenous enzyme products in corn-soy diets (Cowieson and Ravindran, 2008 and Cowieson, 2010). Poultry rations contains different kinds and levels of antinutritional factors which reducing nutrients digestibility like non starch polysaccharides (NSP) compounds (Knudsen, 1997; Bedford, 2000; and $\mathrm{Yu}$ and Chung, 2004). These compounds have the ability to prevent access to 


\section{Selim et al.}

nutrients by encapsulating them (Gracia et al., 2003; Cowieson, 2005; Choct, 2006; and Slominski 2011). Also, corn-soy-based diets contains numerous antinutritional factors, such as $\beta$-glucans, $\beta$-mannose, protease inhibitors and lectins, and it has been proved that the addition of exogenous enzymes in cornsoy-based diets is reasonable and practicable (Yang et al., 2010). Previous studies indicated that NSP concentration in whole corn grain about 27-32 g of xylose/kg (Knudsen, 1997) while soybean meal contained 18-19 g of xylose/kg (Knudsen, 1997; and Irish and Balnave, 1993). NSP can increase digesta viscosity, which has been related to a reduction in starch, protein, and fat digestibility (Bedford et al., 1991; and Meng et al., 2005); however, corn-soy diets may not contain sufficient concentrations of highmolecular weight soluble polysaccharides to increase intestinal viscosity to a point that is detrimental to nutrient utilization by poultry (Gracia et al., 2003; and Knudsen, 2014).

Cowieson (2010) estimated the indigestible energy by feeding typical corn-soy ration by 400 to 450 $\mathrm{kcal}$ of energy per $\mathrm{kg}$ of diet. The author reported that use of exogenous enzymes can be a good strategy to release this energy and make it available to birds. In this trend numerous studies investigated using exogenous carbohydrases such as xylanases has been reported to improve energy utilization and the performance of broilers (Bedford,1995; Olukosi and Adeola, 2008; and Williams et al., 2014) by hydrolysis of cell wall arabinoxylans and improve the access of endogenous digestive enzymes to cell contents (Kocher et al., 2003; Meng et al., 2005; Omar et al., 2008; and Francesch and Geraert, 2009). Choct et al., (1995) mentioned that xylanase was successfully hydrolyze NSP in poultry diet. Bedford (1995) reported that the overall effects of enzymes additives improve live weight and feed conversion ratio and increase the levels of metabolizable energy of the cereal or the ration as a whole. Panda et al., (2012) reported that AME can be reduced by $100 \mathrm{kcal} / \mathrm{kg}$ in maize-soybean meal based broilers diet by supplementing carbohydrase enzyme (xylanase, glucanase, cellulase and mannanase). Abou El-Wafa et al., (2013) reported the same results by adding xylanase to broiler corn-soybean meal based diets. While Youssef et al., (2011) concluded that a mixture of enzyme preparation containing xylanase and amylase added to corn-based diet could reduce the dietary energy level about $150 \mathrm{kcal} / \mathrm{kg}$ without a negative effect on growth performance or carcass traits. Gehring et al., (2013) concluded that responses to exogenous enzyme supplementation are not constant and are influenced by type of feed ingredients and other factors.

The objective of the current study was to evaluate the ability of supplemental xylanase to enhance growth performance, carcass traits, meat quality and feeding cost of broilers fed low energy corn-soybean meal diets.

\section{MATERIALS AND METHODS}

\section{Experimental diets and birds:}

Two hundred and forty unsexed one day old Arbor Acres broiler chicks were wing banded, weighed and randomly allocated in a $2 \times 3$ factorial design in six experimental groups; each group contains four replicates of ten chicks each. Chicks were fed on diets contained the requirements of all nutrients except metabolizable energy (ME). The examined three ME levels were standard requirements of chicks' strain (STD), lower $100 \mathrm{kcal} / \mathrm{kg}$ diet in each feeding phase than STD (E100), and lower $150 \mathrm{kcal} / \mathrm{kg}$ diet in each feeding phase than STD (E150). Two level of xylanase enzyme supplementation (0 and $16000 \mathrm{U}$ xylanase $/ \mathrm{kg}$ diets) were examined. The experimental diets STD, E100 and E150 contained 3000, 2900 and $2850 \mathrm{kcal} / \mathrm{kg}$ during starter period (1-10 d), 3100, 3000 and $2950 \mathrm{kcal} / \mathrm{kg}$ during grower period (11$24 \mathrm{~d}$ ), and 3200, 3100 and $3050 \mathrm{kcal} / \mathrm{kg}$ during finisher period (25-40 d), respectively as described in Table (1). The examined xylanase source was commercial enzyme (Econase XT25) which supplemented at level $100 \mathrm{mg} / \mathrm{kg}$ diet to provide $16000 \mathrm{U}$ xylanase/kg diets. All chicks were fed on examined diets ad libitum in wire battery cages and received the same management and veterinary procedures during the experimental period (1 - $40 \mathrm{~d}$ ). Growth performance parameters including live bodyweight (BW), body weight gain $(\mathrm{BWG})$, feed intake $(\mathrm{FI})$, and feed conversion ratio (FCR) were recorded during feeding phases and the overall experimental period. 
Egyptian J. Nutrition and Feeds (2015)

Table (1): Composition and calculated analysis of experimental diets

\begin{tabular}{|c|c|c|c|c|c|c|c|c|c|}
\hline \multirow[t]{2}{*}{ Ingredient } & \multicolumn{3}{|c|}{ Starter (1-10 days) } & \multicolumn{3}{|c|}{ Grower (11-22 days) } & \multicolumn{3}{|c|}{ Finisher (23-40 days) } \\
\hline & STD & E100 & E150 & STD & E100 & $\mathrm{E} 150$ & STD & E100 & $\mathrm{E} 150$ \\
\hline Yellow corn & 55.10 & 55.00 & 54.90 & 60.65 & 62.31 & 62.55 & 64.74 & 66.51 & 65.7 \\
\hline Soybean meal (44\%) & 31.00 & 33.57 & 36.17 & 23.84 & 24.44 & 25.86 & 19.25 & 19.48 & 23.09 \\
\hline Corn gluten meal (60\%) & 7.50 & 5.88 & 4.00 & 8.57 & 8.00 & 7.00 & 8.16 & 8.0 & 5.30 \\
\hline Soybean oil (SO) & 1.80 & 0.95 & 0.45 & 2.27 & 0.60 & 0.00 & 3.28 & 1.44 & 1.44 \\
\hline Di-Ca-P & 2.00 & 2.00 & 2.00 & 1.75 & 1.75 & 1.75 & 1.55 & 1.55 & 1.55 \\
\hline Limestone & 1.15 & 1.20 & 1.15 & 1.46 & 1.46 & 1.46 & 1.58 & 1.58 & 1.58 \\
\hline $\mathrm{NaCl}$ & 0.24 & 0.24 & 0.24 & 0.24 & 0.24 & 0.24 & 0.24 & 0.24 & 0.24 \\
\hline Vit.\&Min. pre-mix* & 0.40 & 0.40 & 0.40 & 0.40 & 0.40 & 0.40 & 0.40 & 0.40 & 0.40 \\
\hline Sodium bicarbonate & 0.23 & 0.23 & 0.23 & 0.23 & 0.23 & 0.23 & 0.23 & 0.23 & 0.23 \\
\hline DL Methionine & 0.24 & 0.26 & 0.27 & 0.19 & 0.19 & 0.19 & 0.17 & 0.17 & 0.19 \\
\hline L-Lysine $\mathrm{HCl}$ & 0.34 & 0.27 & 0.19 & 0.40 & 0.38 & 0.32 & 0.40 & 0.40 & 0.28 \\
\hline Total & 100.0 & 100.0 & 100.0 & 100.0 & 100.0 & 100.0 & 100.0 & 100.0 & 100.0 \\
\hline Calculated analysis & & & & & & & & & \\
\hline Crude protein $\%$ & 23.00 & 23.00 & 23.00 & 21.00 & 21.00 & 21.00 & 19.00 & 19.00 & 19.00 \\
\hline ME (kcal/kg diet) & 3000 & 2904 & 2850 & 3093 & 3000 & 2950 & 3200 & 3100 & 3050 \\
\hline Crude fiber\% & 3.68 & 3.81 & 3.99 & 3.32 & 3.38 & 3.49 & 3.06 & 3.06 & 3.30 \\
\hline Ether extract $\%$ & 4.52 & 3.97 & 2.97 & 5.05 & 3.52 & 2.92 & 6.21 & 4.37 & 4.21 \\
\hline Calcium \% & 0.98 & 0.97 & 0.98 & 1.00 & 1.00 & 1.00 & 1.00 & 1.00 & 1.00 \\
\hline Available $\mathrm{P} \%$ & 0.52 & 0.52 & 0.53 & 0.47 & 0.46 & 0.47 & 0.42 & 0.42 & 0.42 \\
\hline Sodium \% & 0.17 & 0.17 & 0.17 & 0.17 & 0.17 & 0.17 & 0.17 & 0.17 & 0.17 \\
\hline Lysine \% & 1.38 & 1.38 & 1.38 & 1.24 & 1.26 & 1.24 & 1.11 & 1.11 & 1.11 \\
\hline Methionine \% & 0.67 & 0.68 & 0.67 & 0.60 & 0.60 & 0.60 & 0.55 & 0.55 & 0.55 \\
\hline Methionine+Cystine\% & 1.05 & 1.05 & 1.05 & 0.95 & 0.96 & 0.95 & 0.87 & 0.87 & 0.87 \\
\hline $\begin{array}{l}\text { Cost / ton at } \\
\text { Egyptian Local Price (LE) }\end{array}$ & 3550 & 3471 & 3400 & 3443 & 3327 & 3263 & 3372 & 3260 & 3200 \\
\hline
\end{tabular}

\section{Slaughtering and carcass characteristics:}

At the end of the experiment (40 days of age), four birds of each treatment were slaughtered to record carcass characteristics. Carcass, abdominal fat, edible parts (liver, gizzard and heart) were weighted and calculated as \% from live body weight. Also, Weights of front quarter (FQ) which include breast quarter muscles and skin (without wing) and back quarter (BQ) which include drumstick and thigh were recorded as percentage from carcass weight. While weights including of drumstick (DS) and thigh samples were recorded as percentage of back quarter. Skin weight of every part was recorded as percentage of its part. Then, FQ and BQ samples (72 samples) were kept for $24 \mathrm{~h}$ at $4^{\circ} \mathrm{C}$ to complete the physical and chemical evaluation of broiler meat.

\section{Meat quality measurements:}

\section{Physical measurements:}

After slaughtered 72 samples (24 breast, 24 thigh and 24 drumsticks) samples were subjected to drip loss $\%$ and ultimate $\mathrm{pH}(\mathrm{pHu})$ during the $24 \mathrm{~h}$ after slaughtering. Drip loss\% was calculated as the percentage of the difference between weights of samples before and after storage $24 \mathrm{~h}$. and divided by the first weight as described by Saenmahayak et al., (2012). Samples were lightly blotted using filter paper before reweighting. Concerning pHu, during $24 \mathrm{~h}$ of chilling the samples on $4^{\circ} \mathrm{C}$ were used to measure pHu as described by Selim et al., (2013) using pH meter, provided by a temperature control system, by probe method. The minimum depth to adopt was $1 \mathrm{~cm}$ after incision of the muscles. 


\section{Selim et al.}

\section{Chemical measurements:}

Samples of breast, thigh and drum stick (DS) of each slaughtered bird were homogenized at equal weight basis then stored on $-20^{\circ} \mathrm{C}$ for 60 days before used to determine concentrations of malondialdehyde (MDA), total protein (TP), low density lipoprotein (LDL) and high density lipoprotein (HDL) in meat extract. Meat extract of each sample was prepared by using $10 \mathrm{ml}$ of phosphate buffer $\mathrm{pH}$ 7.4 Colorimetric methods using analytical commercial kits produced by Biodiagnostic Company, Egypt (Selim et al., 2014).

\section{Statistical analysis:}

The collected data were subjected to two way analysis of variance to detect the effects of xylanase supplementation and ME level using the general liner model (GLM) procedure of SAS User's guide (SAS, 2001) as the following model:

$\mathrm{Y}_{\mathrm{ijk}}=\mu+\mathrm{X}_{\mathrm{i}}+\mathrm{M}_{\mathrm{j}}+(\mathrm{XM})_{\mathrm{ij}}+\mathrm{e}_{\mathrm{ijk}}$.

Where:

$\mathrm{Y}_{\mathrm{ijk}} \quad=$ Trait measured

$\mu \quad=$ Overall mean

$\mathrm{X}_{\mathrm{i}}=$ Xylanase supplementation $\mathrm{i}=(1,2)$

$\mathrm{M}_{\mathrm{j}} \quad=$ Metabolizable energy level $\mathrm{j}=(1, ., 3)$

$(\mathrm{XM})_{\mathrm{ij}}=$ Interaction between xylanase supplementation and metabolizable energy level.

$\mathrm{e}_{\mathrm{ijk}} \quad=$ Experimental error

In addition data of all experimental treatments were subjected to one way analysis of variance to detect the differences between all treatments as following model:

Where:

$$
\mathrm{Y}_{\mathrm{ij}}=\mu+\mathrm{Ti}+\mathrm{e}_{\mathrm{ij}}
$$

$\mu=$ overall mean of Yij,

$\mathrm{T}_{\mathrm{i}}=$ effect of treatment, $\mathrm{i}=(1, \ldots, 6)$

$\mathrm{e}_{\mathrm{ij}}=$ Experimental error

In addition data of all experimental treatments were subjected to one way analysis of variance to detect the differences between them. Duncan's Multiple Range test (Duncan's, 1955) was used to separate means when separation was relevant. Statistical significance was accepted at probability level of $(\mathrm{p}<0.05)$.

\section{RESULTS AND DISSCUSION}

\section{Growth performance:}

The recorded results of growth performance parameters of broilers during the experimental period are shown in Table (2). These results showed that xylanase supplementation to corn-soybean meal broiler diets could enhance final BW, BWG and FCR significantly, and could reduce values of FI. The improvement of FCR was $8 \%$ compared with the value of unsupplemented group. Regarding experimental ME levels, reducing $150 \mathrm{kcal} / \mathrm{kg}$ diet led to significant reduction of broiler BW and BWG and increased the consumed feed during the experiment compared to E100 recorded values. This situation led to significant deterioration of FCR by $4.1 \%$ and $14.3 \%$ by using E100 and E150 diets compared with STD diets, respectively. Among experimental treatments, all treatments recorded better BW and BWG except treatment E150 when compared with STD values. Chicks of STD + Xyl and E100 + Xyl treatments recorded the best FCR compared with other treatments (10\% and $4 \%$ improvements compared with STD group). The obtained mean values of growth performance parameters of experimental treatments showed that xylanase supplementation to E150 diets could compensate some of ME reduction 
and help chicks to increase BWG and improve FCR compared with unsupplemented treatment (1949 vs. 1790 and 1.83 vs. 2.01, respectively).

Table (2). Effect of xylanase enzyme supplementation and metabolizable energy level on growth performance of broiler chicks at 40 days of age.

$a, b, \ldots=$ Means in the same column with different superscripts, differ significantly $(P<0.05) ;$ N.S $=$ Non significant . $S T D=$ Standard requirements $X y l=X y l a n a s e ; E 100=100 \mathrm{kcal} / \mathrm{kg}$ diet lower than STD $E 150=150 \mathrm{kcal} / \mathrm{kg}$ diet lower than STD.

\begin{tabular}{|c|c|c|c|c|}
\hline Treatment & $\begin{array}{l}\text { Body weight } \\
\text { (g) }\end{array}$ & $\begin{array}{l}\text { Feed intake } \\
\qquad(\mathrm{g})\end{array}$ & $\begin{array}{l}\text { Body weight gain } \\
\text { (g) }\end{array}$ & $\begin{array}{c}\text { Feed } \\
\text { conversion } \\
\text { ratio }\end{array}$ \\
\hline \multicolumn{5}{|l|}{ Main effect } \\
\hline \multicolumn{5}{|c|}{ - Xylanase Supplementation (16000U/kg) } \\
\hline Without & $1856.16^{\mathrm{b}}$ & $3371.69^{\mathrm{a}}$ & $1816.16^{\mathrm{b}}$ & $1.86^{\mathrm{a}}$ \\
\hline With (Xyl.) & $1968.60^{\mathrm{a}}$ & $3291.42^{b}$ & $1928.60^{\mathrm{a}}$ & $1.71^{\mathrm{b}}$ \\
\hline Mean of SE & \pm 14.31 & \pm 26.99 & \pm 14.31 & \pm 0.01 \\
\hline Probability & 0.0001 & 0.05 & 0.0001 & 0.0001 \\
\hline \multicolumn{5}{|c|}{-Metabolizable Energy $(\mathrm{kcal} / \mathrm{kg})$} \\
\hline STD & $1914.38^{\mathrm{ab}}$ & $3146.81^{\mathrm{c}}$ & $1874.38^{\mathrm{ab}}$ & $1.68^{\mathrm{c}}$ \\
\hline E100 & $1953.13^{\mathrm{a}}$ & $3342.52^{b}$ & $1913.13^{\mathrm{a}}$ & $1.75^{\mathrm{b}}$ \\
\hline E150 & $1869.63^{\mathrm{b}}$ & $3505.32^{\mathrm{a}}$ & $1829.63^{b}$ & $1.92^{\mathrm{a}}$ \\
\hline Mean of SE & \pm 17.53 & \pm 33.06 & \pm 17.53 & \pm 0.02 \\
\hline \multirow{2}{*}{ Probability } & 0.01 & 0.0001 & 0.01 & 0.0001 \\
\hline & & Treatments & & \\
\hline STD & $1846.25^{b}$ & $3194.63^{\text {cd }}$ & $1806.25^{b}$ & $1.77^{\mathrm{b}}$ \\
\hline STD+Xyl & $1982.50^{\mathrm{a}}$ & $3099.00^{\mathrm{d}}$ & $1942.50^{\mathrm{a}}$ & $1.59^{\mathrm{d}}$ \\
\hline E100 & $1932.22^{\mathrm{a}}$ & $3401.04^{\mathrm{ab}}$ & $1892.22^{\mathrm{a}}$ & $1.80^{\mathrm{b}}$ \\
\hline $\mathrm{E} 100+\mathrm{Xyl}$ & $1974.03^{\mathrm{a}}$ & $3284.00^{\mathrm{bc}}$ & $1934.03^{\mathrm{a}}$ & $1.70^{\mathrm{c}}$ \\
\hline E150 & $1790.00^{\mathrm{b}}$ & $3519.39^{\mathrm{a}}$ & $1750.00^{b}$ & $2.01^{\mathrm{a}}$ \\
\hline $\mathrm{E} 150+\mathrm{Xyl}$ & $1949.26^{\mathrm{a}}$ & $3491.25^{\mathrm{a}}$ & $1909.26^{\mathrm{a}}$ & $1.83^{\mathrm{b}}$ \\
\hline Mean of SE & \pm 24.79 & \pm 46.75 & \pm 24.79 & \pm 0.02 \\
\hline Probability & 0.0001 & 0.0001 & 0.0001 & 0.0001 \\
\hline
\end{tabular}

The overall results of growth performance showed that applying STD + xyl and E100 + Xyl diets in feeding broiler may be help producers to gain acceptable broiler weights with improved FCR values.

Concerning xylanase supplementation, the results of the current study were in agree with those reported previously by (Cowieson, 2005; Nian et al., 2011; and Williams et al., 2014; and Pirgozliev et al., (2015). The authors reported improved growth performance of broilers when fed on corn-soybean meal based diets supplemented with xylanase enzyme.

Cowieson et al., (2010) reported significant improvement of FCR of broilers with xylanase supplementation due to increased BWG accompanied with no effect on FI, which suggested that xylanase increased the feed use efficiency (O’Neill and Lui , 2011).

O'Neill et al., (2012) examined the effect of xylanase supplementation to low energy broiler diets (lower $100 \mathrm{kcal} / \mathrm{kg}$ diet than recommendation) based on corn-soybean meal and reported significant improvement of growth performance after the first 21 days of age. They concluded that decreasing ME of broiler diets resulted in worsened performance and xylanase supplementation might improve FCR. On the same trend Abou El-Wafa et al., (2013) found that the effect of dietary ME level reveal a significant decrease in total BWG associated with a corresponding increase in total FI and a worsening in FCR as the 


\section{Selim et al.}

dietary ME decreased 50 and $100 \mathrm{kcal} / \mathrm{kg}$ diet. The same authors reported that inclusion xylanase significantly improved FCR without affecting total BWG. Also, Pirgozliev et al., (2015) showed that xylanase supplementation to broiler diets improved dietary AME.

Reducing ME of broiler diets 100 and $150 \mathrm{kcal} / \mathrm{kg}$ diet than STD resulted in significant depression of BWG and FCR as found in reports of Downs et al.,(2006); Golian et al., (2010); O'Neill et al., (2012); and Abou El-Wafa et al., (2013), and some of them reported associated increase of FI (O'Neill et al., (2012).

Xylanase hydrolyses NSP through breakdown $\beta$ 1-4, D-xylosidic linkage of highly polymerized and substituted $\beta$ 1-4 linked D-xylobiose, xylotriose and glucuronosyl residues. Furthermore, xylanase may create pre-biotic xylo-oligomers that benefit digestion indirectly via increased fermentation in the hindgut and stimulation of the ileal brake mechanism (Cowieson, 2005).

However some experiments showed positive effect of xylanase supplementation to broiler diets on growth performance (Choct et al., 1995; Abou El-Wafa et al., 2013; Williams et al., 2014; and Pirgozliev et al., 2015). On the other side no effect on growth performance with supplementing various carbohydrases (Kocher et al., 2003 and Singh et al., 2012).

\section{Carcass characteristics:}

The recorded results of carcass characteristics of broiler chicks of experimental treatments at $40 \mathrm{~d}$ of age are presented in Table (3). The results showed significant increase of dressing $\%$ and breast meat yield $\%(5.3 \%$ and $7.1 \%)$ by xylanase supplementation, while $\%$ of edible parts and skin of FQ were decreased by $9.4 \%$ and $17 \%$ as compared with unsupplemented group, respectively. Regarding ME of broiler diets, decreasing ME from E100 to E150 caused a significantly reduction (3.9 \%) in dressing \%, however values of abdominal fat \% showed significant reduction by decreasing ME level from STD to E100 and extra numerical reduction by using E150. Although, using E100 diets produced the highest value of breast meat yield (20.33\% from carcass), values of BQ did not changed significantly by using varying ME levels. Reducing ME from STD to E100 or to E150 led to significant increase of drum stick (DS) \% accompanied with significant depression of thigh \%. Between experimental treatments, broilers fed on low ME diets showed significant reduction of abdominal fat \%. Generally chicks fed on diets supplemented with Xy1 either with STD or E100 showed significantly the highest dressing and breast meat yield \%.

The obtained results showed significant enhancement of xylanase supplementation on dressing $\%$ and breast meat yield $\%$ while abdominal fat $\%$ did not affected. These results are in match with those reported by some workers who interested with the effects of xylanase supplementation on carcass traits of broilers and detected significant increase of dressing (Medhi et al., 2003; and Khan et al., 2006). Williams et al., (2014) explained this improvement by increasing the energy utilization of broiler diets fed on xylanase diets. Another suggestion reported by Medhi et al., (2003); and Khan et al., (2006) who suggested the improvement might be due to improve the growth rate of broiler and thereby increased the dressing percentage. Controversy, Abou El-Wafa et al., (2013) examined the effect of xylanase supplementation to broiler diets based on corn or corn/rye at recommended and reduced ME levels (50 and $100 \mathrm{kcal} / \mathrm{kg}$ ) and recorded no significant effect of xylanase on dressing \% but the \% of abdominal fat was decreased by $25.41 \%$ compared with unspplemented group. Furthermore many researchers reported no effect of carbohydrases on dressing \% and general carcass traits of broilers (NarsimhaRao, 1998; and Hanumantharao et al., 2003).

The recorded reduction of abdominal fat $\%$ in current results due to decreased ME in broiler diets were different than those reported previously by some researchers (Abudabos, 2012; Abou El-Wafa et al., 2013; Williams et al., 2014; and Miah et al., 2014). These reports showed no significant effect of using low ME broiler diets (reduction levels varied from 40 to $170 \mathrm{kcal} / \mathrm{kg}$ ) on dressing $\%$, abdominal fat $\%$ or the overall carcass characteristics. 
Egyptian J. Nutrition and Feeds (2015)

Table 3 


\section{Selim et al.}

\section{Meat quality:}

Effect of xylanase supplementation and ME levels of broiler diets on some quality measurements of broiler meat are shown in Table (4). The presented results showed that xylanase supplementation to cornsoybean meal broiler diets caused significant reduction of $\mathrm{pHu}$ of both breast meat and thigh accompanied with significant reduction of drip loss $\%$ of thigh. Both drip loss $\%$ and $\mathrm{pHu}$ of DS did not affected significantly by xylanase supplementation. On the other side the determined values of broiler meat chemical quality measurements (MDA, LDL, HDL and TP) did not changed as a response to xylanase supplementation. Regarding of ME of broiler diets, reducing ME either 100 or $150 \mathrm{kcal} / \mathrm{kg}$ than broiler requirements led to significant reduction of $\mathrm{pHu}$ of breast samples while only E100 reduce significantly breast meat drip loss $\%$. No significant effect on drip loss $\%$ and $\mathrm{pHu}$ was detected in other cuts. Furthermore, determined concentrations of MDA and LDL of meat samples were reduced by decreasing ME of diets associated with increased concentrations of meat TP significantly.

Table (4): Effect of xylanase enzyme supplementation and metabolizable energy level on some physical and chemical meat quality of broiler chicks at $\mathbf{4 0}$ days of age.

\begin{tabular}{|c|c|c|c|c|c|c|c|c|c|c|}
\hline \multirow[b]{3}{*}{ Treatment } & \multicolumn{6}{|c|}{ Physical measurements } & \multirow{2}{*}{\multicolumn{4}{|c|}{ Chemical measurements }} \\
\hline & \multicolumn{2}{|c|}{ Breast } & \multicolumn{2}{|c|}{ Thigh } & \multicolumn{2}{|c|}{ Drum Stick } & & & & \\
\hline & $\begin{array}{l}\text { Drip } \\
\text { Loss }\end{array}$ & $\mathrm{pHu}$ & $\begin{array}{l}\text { Drip } \\
\text { Loss }\end{array}$ & $\mathrm{pHu}$ & $\begin{array}{l}\text { Drip } \\
\text { Loss }\end{array}$ & $\mathrm{pHu}$ & $\begin{array}{c}\text { MDA } \\
\text { (nmol/100 } \\
\text { g meat) }\end{array}$ & $\begin{array}{c}\text { T.P } \\
\text { (mg/100g } \\
\text { meat) }\end{array}$ & $\begin{array}{c}\text { LDL } \\
\text { (mg/100g } \\
\text { meat) }\end{array}$ & $\begin{array}{c}\text { HDL } \\
\text { (mg/100g } \\
\text { meat) }\end{array}$ \\
\hline Main effect & & & & & & & & & & \\
\hline \multicolumn{11}{|c|}{ - Xylanase Supplementation (16000U/kg) } \\
\hline Without & 3.19 & $6.15^{\mathrm{a}}$ & $4.48^{\mathrm{a}}$ & $6.59^{\mathrm{a}}$ & 1.26 & 6.42 & 392.64 & 65.41 & 1100.00 & 686.78 \\
\hline With (Xyl.) & 2.87 & $5.87^{b}$ & $3.84^{\mathrm{b}}$ & $6.31^{\mathrm{b}}$ & 1.04 & 6.52 & 363.22 & 69.76 & 1073.81 & 698.24 \\
\hline Mean of SE & \pm 0.11 & \pm 0.07 & \pm 0.15 & \pm 0.07 & \pm 0.09 & \pm 0.4 & \pm 18.52 & \pm 1.64 & \pm 32.78 & \pm 17.14 \\
\hline Probability & N.S & 0.01 & 0.01 & 0.01 & N.S & N.S & N.S & N.S & N.S & N.S \\
\hline \multicolumn{11}{|c|}{ Metabolizable Energy (kcal/kg) } \\
\hline STD & $3.46^{\mathrm{a}}$ & $6.88^{\mathrm{a}}$ & 4.37 & 6.50 & 1.32 & 6.40 & $461.03^{\mathrm{a}}$ & $48.21^{\mathrm{b}}$ & $1338.33^{\mathrm{a}}$ & 671.06 \\
\hline E100 & $2.50^{\mathrm{b}}$ & $5.54^{\mathrm{b}}$ & 3.79 & 6.37 & 1.01 & 6.50 & $361.27^{\mathrm{b}}$ & $75.05^{\mathrm{a}}$ & $945.48^{\mathrm{b}}$ & 684.14 \\
\hline E150 & $3.13^{\mathrm{a}}$ & $5.62^{b}$ & 4.31 & 6.47 & 1.14 & 6.50 & $311.50^{\mathrm{b}}$ & $79.49^{\mathrm{a}}$ & $976.91^{\mathrm{b}}$ & 722.33 \\
\hline Mean of SE & \pm 0.14 & \pm 0.08 & \pm 0.18 & \pm 0.08 & \pm 0.11 & \pm 0.05 & \pm 22.68 & \pm 2.00 & \pm 40.15 & \pm 20.99 \\
\hline Probability & 0.001 & 0.0001 & N.S & N.S & N.S & N.S & 0.002 & 0.0001 & 0.0001 & N.S \\
\hline \multicolumn{11}{|c|}{ Treatments } \\
\hline STD & $3.62^{\mathrm{a}}$ & $7.20^{\mathrm{a}}$ & $4.73^{\mathrm{a}}$ & $6.57^{\mathrm{ab}}$ & 1.42 & 6.40 & $506.10^{\mathrm{a}}$ & $43.78^{\mathrm{c}}$ & $1367.14^{\mathrm{a}}$ & $727.51^{\mathrm{ab}}$ \\
\hline STD+Xyl & $3.30^{\mathrm{ab}}$ & $6.55^{\mathrm{b}}$ & $4.01^{\mathrm{ab}}$ & $6.44^{\mathrm{ab}}$ & 1.21 & 6.42 & $415.96^{\mathrm{ab}}$ & $52.65^{\mathrm{b}}$ & $1309.52^{\mathrm{a}}$ & $614.60^{c}$ \\
\hline E100 & $2.90^{\mathrm{b}}$ & $5.67^{\mathrm{c}}$ & $4.22^{\mathrm{a}}$ & $6.52^{\mathrm{ab}}$ & 1.03 & 6.47 & $364.32^{\mathrm{bc}}$ & $74.90^{\mathrm{a}}$ & $1005.71^{\mathrm{b}}$ & $640.44^{\mathrm{bc}}$ \\
\hline E100+Xyl & $2.10^{\mathrm{c}}$ & $5.41^{\mathrm{c}}$ & $3.35^{\mathrm{b}}$ & $6.22^{\mathrm{b}}$ & 0.99 & 6.54 & $358.22^{\mathrm{bc}}$ & $75.20^{\mathrm{a}}$ & $885.24^{\mathrm{b}}$ & $727.83^{\mathrm{ab}}$ \\
\hline E150 & $3.06^{\mathrm{ab}}$ & $5.58^{\mathrm{c}}$ & $4.48^{\mathrm{a}}$ & $6.68^{\mathrm{a}}$ & 1.34 & 6.39 & $307.51^{\mathrm{c}}$ & $77.55^{\mathrm{a}}$ & $927.14^{\mathrm{b}}$ & $692.39^{\mathrm{abc}}$ \\
\hline E150+Xyl & $3.20^{\mathrm{ab}}$ & $5.67^{\mathrm{c}}$ & $4.14^{\mathrm{ab}}$ & $6.26^{\mathrm{b}}$ & 0.93 & 6.62 & $315.49^{\mathrm{bc}}$ & $81.42^{\mathrm{a}}$ & $1026.67^{\mathrm{b}}$ & $752.28^{\mathrm{a}}$ \\
\hline Mean of SE & \pm 0.48 & \pm 0.25 & \pm 0.54 & \pm 0.10 & \pm 0.24 & \pm 0.07 & \pm 32.07 & \pm 2.84 & \pm 56.78 & \pm 29.69 \\
\hline Probability & 0.003 & 0.0001 & 0.04 & 0.09 & N.S & N.S & 0.008 & 0.0001 & 0.0002 & 0.04 \\
\hline
\end{tabular}

$a, b, \ldots=$ Means in the same column with different superscripts, differ significantly $(P<0.05) ;$ N.S $=$ Non significant.

$S T D=$ Standard requirements; $X y l=X y l a n a s e ; E 100=100 \mathrm{kcal} / \mathrm{kg}$ diet lower than $S T D ; \quad E 150=150 \mathrm{kcal} / \mathrm{kg}$ diet lower than STD.

Among experimental treatments the most influenced cut was breast meat whereas its determined $\mathrm{pHu}$ and drip loss \% were significantly affected by treatments. There was general reduction in $\mathrm{pHu}$ values of breast meat in samples of all treatments compared with STD value, while only E100 and E100+Xyl samples showed significantly decrease of drip loss \% compared with that value of STD treatment. The 
lowest $\mathrm{pHu}$ and drip loss \% values of thigh recorded by E100+Xyl. The worst values of TP, MDA and LDL concentrations recorded for STD samples at high significant levels.

The overall results of broiler physical and chemical meat quality examination showed clear improvement of breast meat $\mathrm{pHu}$ by both xylanase supplementation and low ME level and general enhancement of chemical quality and self life of produced meat. Samples of E100+Xyl treatments showed general better meat characteristics compared with other treatments. These results were in agreement with those reported by (Allen et al., 1997; Tang et al., 2007; and Zakaria et al., 2010) about effect of xylanase or ME on broiler meat. Tang et al. (2007) found that $\mathrm{pH}$ value of broiler meat increased by the increasing energy level of diets. In addition decreasing $\mathrm{pH}$ value of broiler meat with xylanase supplementation to low energy broiler diets resulted in increase shelf-life of muscles (Allen et al., 1997). Controversially, some other researchers could not report that improvement either in physical or chemical quality of meat by using carbohydrate enzymes preparations in broiler diets (Jeroch et al., 1991). Zakaria et al. (2010) used commercial enzyme preparation containing carbohydratases and failed to detect significant change of $\mathrm{pH}$, cooking loss and water holding capacity of broiler meat.

According to the reported relationship between $\mathrm{pH}$ and ability to glycogen storage in breast meat by Le-Bihan-Duval etal. (2008), the reported reduction of breast $\mathrm{pHu}$ in this study due to xylanse supplementation or reducing ME of diets proved that glycogen storage in breast meat was increased. Based on results of $\mathrm{pHu}$ and drip loss \%, the ability of breast and thigh meat to processing might be increased whereas water holding capacity and glycogen were increased (Barbut, 1993 and Zhang and Savage, 2010) by xylanase supplementation or reducing ME of diet whereas pHu and drip loss \% decreased.

\section{Feeding cost:}

Results in Table (5) showed the effect of experimental treatments on feeding cost $/ \mathrm{bird}$, feeding cost $/ \mathrm{kg}$ of live BW in Egyptian pounds. In addition feeding cost of STD group was considered to be the basic feeding cost and the differences of feeding cost of other treatments were calculated relative to it in $\%$. The calculated values showed that xylanase supplementation to STD and E100 diets resulted in $9.25 \%$ and $3.51 \%$ saving in feeding cost $/ \mathrm{kg}$ BW of broiler chicks relative to cost STD group. On the other side reducing $\mathrm{ME}$ of broiler diets by 100 and $150 \mathrm{kcal} / \mathrm{kg}$ diets without extra xylanase supplementation led to increased feeding cost by 1.57 and $13.59 \%$ relative to STD, respectively. Although Xylanase supplementation to E150 diets helped chicks to compensate the reduced ME and reducing feeding cost $/ \mathrm{kg}$ BW (4.06 vs $13.59 \%$ increasing cost), the obtained improvement in growth performance was not sufficient to record saving in feeding cost compared with STD value. The greatest saving \% in feeding cost recorded by STD+Xyl group followed by E100+Xyl group ( 9.25 and $3.51 \%$, respectively). 
Table (5): Effect of experimental treatments on feeding cost of broiler chicks during 40 days of age.

\begin{tabular}{lcccccc}
\hline Treatment & $\begin{array}{c}\text { Final } \\
\text { BW } \\
(\mathrm{g})\end{array}$ & $\begin{array}{c}\text { Total } \\
\text { BWG } \\
(\mathrm{g})\end{array}$ & FCR & $\begin{array}{c}\text { Feeding } \\
\text { cost/bird } \\
(\mathrm{LE})\end{array}$ & $\begin{array}{c}\text { Feeding } \\
\text { cost/kg of } \\
\mathrm{BW}(\mathrm{LE})\end{array}$ & $\begin{array}{c}\text { Relative difference of } \\
\text { feeding cost from } \\
\text { STD* }(\%)\end{array}$ \\
\hline STD & 1846 & 1806 & 1.77 & 10.89 & 6.03 & -- \\
STD+Xyl & 1982 & 1942 & 1.59 & 10.63 & 5.47 & 9.25 (Saving cost) \\
E100 & 1932 & 1892 & 1.80 & 11.59 & 6.12 & 1.57 (Increasing cost) \\
E100+Xyl & 1974 & 1934 & 1.70 & 11.25 & 5.82 & 3.51 (Saving cost) \\
E150 & 1790 & 1750 & 2.01 & 11.99 & 6.85 & 13.59 (Increasing cost) \\
E150+Xyl & 1949 & 1909 & 1.83 & 11.98 & 6.27 & 4.06 (Increasing cost) \\
\hline$*$ Relative difference of feeding cost from STD $=100$ x (Feeding cost/kg of BW of each treatment - Feeding cost/kg \\
of BW of STD group)/Feeding cost/kg of BW of STD group). STD = Standard requirements; Xyl = Xylanase; \\
E100 = 100 kcal/kg diet lower than STD; E150=150 kcal/kg diet lower than STD.
\end{tabular}

\section{CONCLUSION}

According to the obtained results of xylanasae enzyme supplementation to low metabolizable energy corn-soybean meal broiler diets on growth performance, carcass traits, meat quality and feeding cost $/ \mathrm{kg}$ of body weight, it could be concluded that adding xylanase at $16000 \mathrm{U} / \mathrm{kg}$ diet to either STD or E100 broiler corn-soybean meal diets could enhance the quality of produced broilers accompanied with saving in feeding cost.

\section{REFERENCES}

Abou El-Wafa, S.; S. M. Shalash; N. A. Selim; Abdel-Khalek; A.M. Radwan and A. F. Abdel- Salam (2013). Response of broiler chicks to xylanase supplementation of corn/rye containing diets varying in metabolizable energy. Int. J. Poult. Sci., 12 (12): 705-713.

Abudabos, A. M. (2012). Effect of enzyme supplementation to normal and low density broiler diets based on corn-soybean meal. Asian J. of Anim. and Veterinary Advances, 7 (2): 139-148. 29 ref.

Allen, C.D.; S.M. Russell and D.L. Fletcher (1997). The relationship of broiler breast meat color and $\mathrm{pH}$ to shelf-life and odor development. Poult. Sci., 76:1042-1046.

Barbut, S. (1993). Colour measurements for evaluating the pale soft exudative (PSE) occurrence in turkey meat. Food Res. Int., 26: 39-43.

Bedford, M. R. (1995). Mechanism of action and potential environmental benefits from the use of feed enzymes. Anim. Feed Sci. Technol., 53:145-155.

Bedford, M. R.; H. L. Classen and G. L. Campbell (1991). The effect of pelleting, salt and pentosanase on the viscosity of intestinal contents and the performance of broilers fed rye. Poult. Sci. 70:1571-1577.

Bedford, M.R. (2000). Exogenous enzymes in monogastric nutrition-their current value and future benefits. Anim. Feed Sci. and Tec., 86: 1-13.

Choct, M. (2006). Enzymes for the feed industry: Past, present and future. World's Poult. Sci. J. 62:5-16.

Choct, M.; R. J. Huges; R. P. Trimble; K. Angkanoporn and G. Annison (1995). Non-starch polysaccharide degrading enzymes increase the performance of broiler chickens fed wheat and low apparent metabolizable energy. J. Nutr., 125: 485: 492. 
Cowieson, A. J. (2005). Factors that affect the nutritional value of maize for broilers. Anim. Feed Sci. Technol. 119:293-305.

Cowieson, A. J. (2010). Strategic selection of exogenous enzymes for corn/soy-based poultry diets. Jpn. Poult. Sci. 47:1-7.

Cowieson, A. J. and V. Ravindran (2008). Sensitivity of broiler starters to three doses of an enzyme cocktail in maize-based diets. Br. Poult. Sci. 49:340-346.

Cowieson, A. J.; M. R. Bedford and V. Ravindran (2010). Interactions between xylanase and glucanase in maize-soy-based diets for broilers. Br. Poult. Sci. 51:246-257.

Downs, K.; R. Lien; J. Hess; S. Bilgili and W. Dozier (2006). The effects of photoperiod length, light intensity and feed energy on growth responses and meat yield of broilers. J. Appl. Poult. Res., 15: 406-416.

Duncan, D. B. (1955). Multiple range and multiple F tests. Biometrics, 11: 1-42.

Francesch, M. and P. A. Geraert (2009). Enzyme complex containing carbohydrases and phytase improves growth performance and bone mineralization of broilers fed reduced nutrient cornsoybeanbased diets. Poult. Sci. 88:1915-1924

Gehring, C. K.; M. R. Bedford and W. A. Dozier (2013). Interactive effects of phytase and xylanase supplementation with extractable salt-soluble protein content of corn in diets with adequate calcium and nonphytate phosphorus fed to broilers. Poult. Sci. 92(7):1858-1869.

Golian, A.; M. Azghadi and M. Pilevar (2010). Influence of various levels of energy and protein on performance and humoral immune responses in broiler chicks. Global Vet., 4: 434-440.

Gracia, M. I.; M. J. Aranibar; R. Lazaro; P. Medel and G. G. Mateos (2003). Alpha-amylase supplementation of broiler diets based on corn. Poult. Sci. 82:436-442.

Hanumantharao, M.; V. Ravinder Reddy and V. Ramasubba Reddy (2003). Effect of commercial enzymes on the performance of broiler, Indian J. of Poult. Sci., 38(3), 291-293.

Irish, G.G. and D. Balnave (1993). Non-starch polysaccharides and broiler performance on diets containing soybean meal as the sole protein concentrate. Aust J. Agric. Res. 44, 1483-1499.

Jeroch, H.; E. Helander; H. J. Schloffel; K. H. Engerer; H. Pingel and G. Gebhardt (1991). Effect of beta -glucanase containing enzyme preparation AvizymeReg. with a barley-based broiler finisher feed. [German] Archiv fur Geflugelkunde. 55(1):22-25. 17 ref.

Khan, S. H.; R. Sardar and B. Siddique (2006). Influence of enzymes on performance of broilers fed sunflower-corn based diets. Pak. Vet. J., 26: 109-114.

Knudsen, B. K. E. (1997). Carbohydrate and lignin contents of plant materials used in animal feeding. Anim. Feed Sci. Technol. 67:319-338. as related to nonruminants: a review. Livest Prod. Sci. 97, pp. $1-12$

Knudsen, B. K. E. (2014). Fiber and non-starch polysaccharide content and variation in common crops used in broiler diets. Poult. Sci. 93:2380-2393.

Kocher, A.; M. Choct; G. Ross; J. Broz and T. K. Chung (2003). Effects of enzyme combinations on apparent metabolizable energy of corn-soybean meal based diets in broilers. J. Appl. Poult. Res. 12:275-283.

Le Bihan-Duval, E.; M. Debut; C. Berri; N. Sellier; V. Santé-Lhoutellier; Y. Jégo and C. Beaumont (2008). Chicken meat quality: genetic variability and relationship with growth and muscle characteristics. BMC Genet., 9:53. 


\section{Selim et al.}

Medhi, D.; H. F. Ahmed; B. K. Konwar and P. Chakravarty (2003). Influence of enzyme supplementation in high fibre diet on the carcass yield and mortality rate of broilers. Indian J. Anim. Nutr., 20: 232236.

Meng, X.; B. A. Slominski; C. M. Nyachoti; L. D. Campbell and W. Guenter (2005). Degradation of cell wall polysaccharides by combinations of carbohydrase enzymes and their effect on nutrient utilization and broiler chicken performance. Poult. Sci. 84: 37-47.

Miah, M. Y.; S. D. Chowdhury; A. K. F. H. Bhuiyan and M. S. Ali (2014). Effect of different levels of dietary energy on growth performance of indigenous desichicks reared in confinement up to target weight of $950 \mathrm{~g}$. Livestock Research for Rural Development 26 (7). from http://www.lrrd.org/lrrd26/7/miah26124.html.

NarsimhaRao, P.V. (1998). Effect of enzymes in feed on broiler performance, M V Sc. Thesis ANGR Agricultural University, Hyderabad.

Nian F.; Y. M. Guo; Y. J. Ru; A. Péron and F. D. Li (2011). Effect of xylanase supplementation on the net energy for production, performance and gut microflora of broilers fed corn/soy-based diet. AsianAust. J. Anim. Sci. 24(9):1282-1287.

O’Neill, M. H. V.; G. Mathis; B. S. Lumpkins and M. R. Bedford (2012). The effects of reduced calorie diets, with and without fat, and the use of xylanase on performance characteristics of broilers between 0 and 42 days. Poult. Sci. 91:1356-1360.

O’Neill, M. H. V. and N. Lui (2011). Effect of xylanase on performance and apparent metabolisable energy in starter broilers fed diets containing one maize variety harvested in different regions of china. Asian-Australas. J. Anim. Sci. http://dx.doi. org/http://dx.doi.org/10.5713/ajas.2011.11314. In press.

Olukosi, O. A. and O. Adeola (2008). Whole body nutrient accretion, growth performance and total tract nutrient retention responses of broilers to supplementation of xylanase and phytase individually or in combination in wheat-soybean meal based diets. J. Poult. Sci. 45:192-198.

Omar, A.W.; M. H. Khataibeh and K. Abu-Alruz (2008). The use of xylanases from different microbial origin in bread making and their effects on bread quality. J. Appl. Sci., 8: 672-676.

Panda, A. K.; G. Lavanandya; E. P. K. Reddy; S. V. R. Rao and M. V. L. N. Raju (2012). Effect of dietary supplementation of enzymes on performance of broiler chickens in maize-soybean meal based diet. Anim. Nutr. and Feed Technol., 12: 297-303.

Pirgozliev V.; F. Karadas; S.P. Rose; A. Beccaccia; M. W. Mirza and A. M. Amerah (2015). Dietary xylanase increases hepatic vitamin E concentration of chickens fed wheat based diet. J. of Anim. and Feed Sci., 24: 80-84

Saenmahayak, B.; M. Singh; S. F. Bilgili and J. B. Hess (2012). Influence of dietary supplementation with complexed zinc on meat quality and shelf life of broilers. Int. J. Poult. Sci., 11: 28-32.

SAS, Statistical analysis system (2001). User's Guide Version 8.2, Cary NC. USA.

Selim, N.A.; A. M. Refaie; A. R. Khosht and A. S. Abd El-Hakim (2014). Effect of sources and inclusion levels of zinc in broiler diets containing different vegetable oils during summer season conditions on meat quality. Int. J. Poult. Sci., 13 (11): 619-626.

Selim, N.A.; Sh. A. Nada; A.F. Abdel-Salam and S. F. Youssef (2013). Evaluation of some natural antioxidant sources in broiler diets: 2-Effect on chemical and microbiological quality of chilled and frozen broiler meat. Int. J. Poult. Sci., 12: 572-581.

Singh, A.; H. V. Masey O’Neill; T. K. Ghosh; M. R. Bedford and S. Haldar (2012). Effects of xylanase supplementation on performance, total volatile fatty acids and selected bacterial population in caeca, metabolic indices and peptide YY concentrations in serum of broiler chickens fed energy restricted maize-soybean based diets. Anim. Feed Sci. Technol. 177:194-203. 
Slominski, B. A. (2011). Recent advances in research on enzymes for poultry diets. Poult. Sci. 90:20132023.

Tang M. Y.; Q. G. Ma; X. D. Chen and C. Ji (2007). Effects of dietary metabolizable energy and lysine on carcass characteristics and meat quality in arbor acres broilers. Asian-Aust. J. Anim. Sci. 20(12): 1865-1873

Williams M. P.; J. T. Klein; C. L. Wyatt; T. W. York and J. T. Lee (2014). Evaluation of xylanase in lowenergy broiler diets. J. Appl. Poult. Res. $23: 1-8$ http://dx.doi.org/ 10.3382/japr.2013-00856.

Yang Z.; W. Yang and S. Jiang (2010). Effects of a thermotolerant multi-enzyme product on nutrient and energy utilization of broilers fed mash or crumbled corn-soybean meal diets. J. Appl. Poult. Res., 19(1):38-45.

Youssef, A.; H. Ali and M. Mohamed (2011). Performance, abdominal fat and economic efficiency of broiler fed different energy levels supplemented with xylanase and amylase from 14 to 40 dayse of age. World J. Agric. Sci. 7: 291- 297.

Yu, B. and T. K. Chung (2004). Effects of multiple-enzyme mixtures on growth performance of broilers fed corn-soy meal diets. J. Appl. Poult. Res. 13:178-182.

Zakaria, H. A. H.; M. A. R. Jalal and M. A. A. Ishmais (2010). The influence of supplemental multienzyme feed additive on the performance, carcass characteristics and meat quality traits of broiler chickens. Inter. J. of Poult. Sci., 9(2):126-133. 49 ref.

Zhang, H. and E. M. Savage (2010). Comparisons of sensory descriptive flavor and texture profiles of cooked broiler breast fillets categorized by raw meat color lightness values. Poult. Sci. 89:1049-1055. 
الفو ائد الإضافية لإنزيم الزيلينيز فى علانق الأذره وكسب فول الصويا المنذفضه فى الطاقه لكتاكيت التسمين

نسرين عبدالسلام سليم و امانى حسين والى وهمت عبدالعال عبدالمجيد و هبه حامد حبيب و احمد عبد التواب فضل و سيد محمد شلش قسم تغذية الدواجن- معهل بحوث الإتتاج الحيوانح- مركز البحوث الزراعيهـ الدقى - الجيزه.

تهدف هذه التجربه اللى دراسة قدرة إنزيم الزيلينيز المضاف على تحسين أداء النمو و صفات الذبيحه و جودة اللحم وتكاليف التغذيه

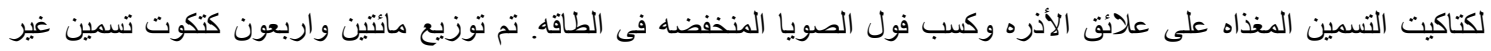

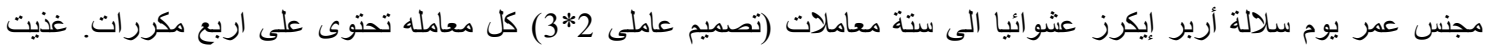

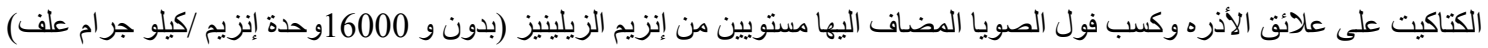

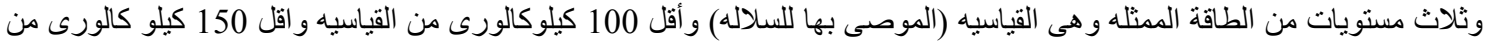
القياسيه ( E100 و E150 على التوالى) وذلك لكل مرحله تنذيه. و كانت مستويات الطاقه بالعلائق

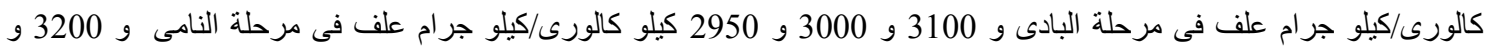

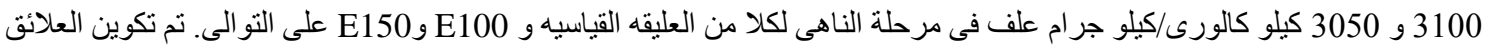

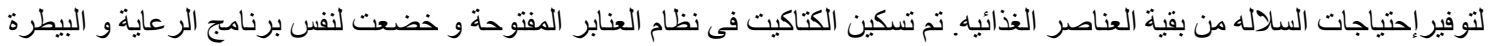

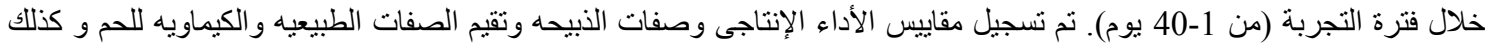

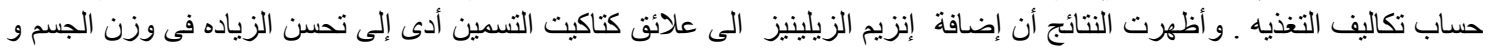

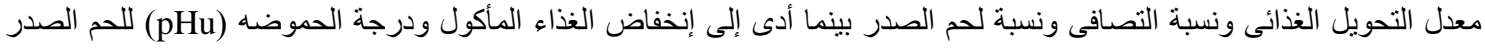

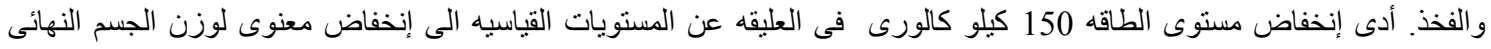

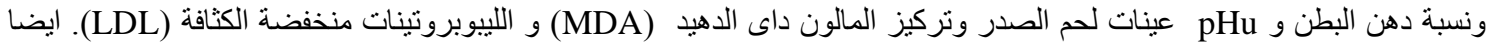

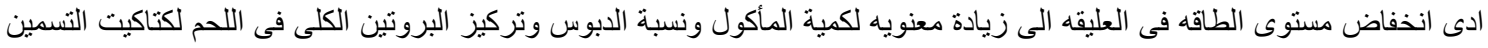

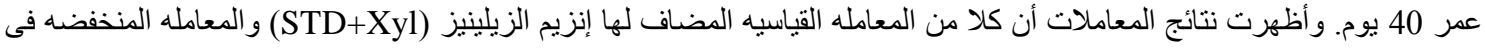

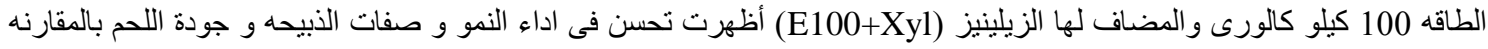

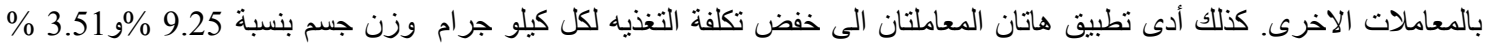

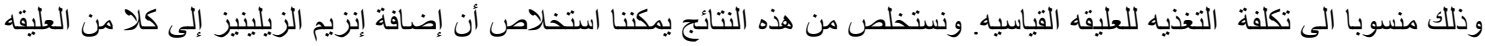
القياسيه و العليقه المنخفضه فى الطاقه بمقدار 100 كيلو كالورى يؤدى إلى تحسن جودة الكتاكيت المنتجه مع توفير فى تكاليف التغذيه. 